\title{
URGENSI BADAN USAHA MILIK DESA (BUMDES) DALAM PEMBANGUN PEREKONOMIAN DESA
}

\author{
Zulkarnain Ridlwan \\ Fakultas Hukum Unila \\ Email : zulkarnain.ridlwan@fh.unila.ac.id
}

\begin{abstract}
The purpose of this paper is to describe the importance of village-owned enterprises and the management in the interests of rural communities. Referring to the legislation governing the rural , particularly Law No. 6 of 2014 , it can be concluded that the village-owned enterprises is a village economic institution that has an important role in the welfare of the community, the village, and the village government. A professional governance that refers to the guidelines in the formation of village-owned enterprises based on legislation is a prerequisite of village-owned enterprises goes properly. Thus the economic activities of village-owned enterprises should ideally be part of efforts to increase local and regional economies within the scope of the national economy.
\end{abstract}

Keywords: Urgency of Village-Owned Enterprises, Formation and Management.

\section{abstrak}

Tujuan penulisan ini adalah mendeskripsikan pentingnya keberadaan Badan Usaha Milik Desa (BUMDes) dan pengelolaannya guna kepentingan masyarakat desa. Merujuk pada peraturan perundang-undangan yang mengatur tentang desa, khususnya UU Nomor 6 Tahun 2014, disimpulkan bahwa BUMDes merupakan suatu lembaga perekonomian desa yang memiliki peranan penting dalam mewujudkan kesejahteraan masyarakat, desa, dan pemerintah desa. Tata kelola yang profesional dengan mengacu pada pedoman pembentukan BUMDes berdasarkan peraturan perundangundangan menjadi prasyarat berjalannya BUMDes secara baik. Dengan demikian kegiatan ekonomi BUMDes secara ideal dapat menjadi bagian dari usaha peningkatan ekonomi lokal dan regional dalam lingkup perekonomian nasional.

Kata Kunci : Urgensi BUMDes, Pembentukan dan Pengelolaan 


\section{A. Pendahuluan}

Secara historis desa merupakan cikal bakal terbentuknya masyarakat politik dan pemerintahan di Indonesia jauh sebelum negara-bangsa ini terbentuk. Struktur sosial sejenis desa, masyarakat adat dan lain sebagainya telah menjadi institusi sosial yang mempunyai posisi yang sangat penting. ${ }^{1}$ Undang-undang yang mengatur khusus mengatur tentang desa kini telah ada. ${ }^{2}$ Pemerintah telah mengesahkan Undang-Undang Nomor 6 Tahun 2014 tentang Desa (UU Desa). Tujuan ditetapkannya pengaturan desa dalam UU ini merupakan penjabaran lebih lanjut dari ketentuan sebagaimana dimaksud dalam Pasal 18 ayat (7) dan Pasal 18B ayat (2) Undang-Undang Dasar Negara Republik Indonesia Tahun 1945, yaitu:

1. memberikan pengakuan dan penghormatan atas desa yang sudah ada dengan keberagamannya sebelum dan sesudah terbentuknya Negara Kesatuan Republik Indonesia;

2. memberikan kejelasan status dan kepastian hukum atas desa dalam sistem ketatanegaraan Republik Indonesia demi mewujudkan keadilan bagi seluruh rakyat Indonesia;

3. melestarikan dan memajukan adat, tradisi, dan budaya masyarakat desa;

4. mendorong prakarsa, gerakan, dan partisipasi masyarakat desa untuk pengembangan potensi dan aset desa guna kesejahteraan bersama;

5. membentuk pemerintahan desa yang profesional, efisien dan efektif, terbuka, serta bertanggung jawab;

6. meningkatkan pelayanan publik bagi warga masyarakat desa guna mempercepat perwujudan kesejahteraan umum;

7. meningkatkan ketahanan sosial budaya masyarakat desa guna mewujudkan masyarakat desa yang mampu memelihara kesatuan sosial sebagai bagian dari ketahanan nasional;

8. memajukan perekonomian masyarakat desa serta mengatasi kesenjangan pembangunan nasional; dan

9. memperkuat masyarakat desa sebagai subjek pembangunan.

Konsideran UU tersebut menegaskan latar belakang dibuatnya UU Desa dengan kalimat “...dalam perjalanan ketatanegaraan Republik Indonesia, desa telah berkembang dalam berbagai bentuk sehingga perlu dilindungi dan diberdayakan agar menjadi kuat, maju, mandiri, dan demokratis sehingga dapat menciptakan landasan yang kuat dalam

\footnotetext{
${ }^{1}$ H.A.W. Widjaja, Otonomi Desa: Merupakan Otonomi Yang Asli, Bulat dan Utuh,(Jakarta: RajaGrafindo, 2010), hlm. 4.

2 Sebelumnya pengaturan tentang Desa menjadi bagian dari UU mengenai Pemerintahan Daerah, meski dalam bentuk peraturan pemerintah telah ada. Lihat Arief Muljadi, Landasan dan Prinsip Hukum Otonomi Daerah dalam NKRI, (Jakarta: Prestasi Pustaka, 2005), hlm. 101-102.

${ }^{3}$ Penjelasan UU Nomor 6 Tahun 2014.
} 
melaksanakan pemerintahan dan pembangunan menuju masyarakat yang adil, makmur, dan sejahtera".

Desa yang telah berkembang perlu perlindungan dan pemberdayaan sehingga menjadi:

1. desa kuat;

2. desa maju;

3. desa mandiri; dan

4. desa demokratis.

Implikasi dari terbentuknya desa dengan sifat yang demikian, diharap dapat menjadi landasan yang kuat dalam melaksanakan pemerintahan dan pembangunan menuju masyarakat yang adil, makmur, dan sejahtera. Kesan kuat yang dapat terlihat dari pertimbangan dalam pembentukan UU Desa adalah keinginan pemerintah untuk membentuk kelembagaan desa yang lebih maju, salah satunya dalam aspek ekonomi.

UU Desa dalam rangka pembangunan aspek ekonomi desa tersebut mengatur adanya badan usaha yang dimiliki desa. Meski substansi mengenai badan usaha milik desa (BUMDes) bukanlah hal yang baru dalam peraturan tentang pemerintahan desa $^{4}$, namun pada aspek kemandirian, UU Desa memberi penekanan lebih. Kemandirian yang dimaksud yaitu suatu proses yang dilakukan oleh pemerintah desa dan masyarakat desa untuk melakukan suatu kegiatan dalam rangka memenuhi kebutuhannya dengan kemampuan sendiri.

Pengalaman pemerintahan desa memberi pelajaran bagi pengelolaan hubungan desa, satu pendekatan baru yang diharapkan mampu menstimuli dan menggerakan roda perekonomian di pedesaan. Stimuli yang dimaksud adalah melalui pendirian kelembagaan ekonomi yang dikelola sepenuhnya oleh masyarakat desa. Lembaga ekonomi ini tidak lagi didirikan atas dasar instruksi pemerintah. Tetapi harus didasarkan pada keinginan masyarakat desa yang berangkat dari adanya potensi yang jika dikelola dengan tepat akan menimbulkan permintaan di pasar. Agar keberadaan lembaga ekonomi ini tidak dikuasai oleh kelompok tertentu yang memiliki modal besar di pedesaan. Maka kepemilikan lembaga itu oleh desa dan dikontrol bersama di mana tujuan utamanya untuk meningkatkan standar hidup ekonomi masyarakat.

Pendirian lembaga ini antara lain dimaksudkan untuk mengurangi peran para tengkulak yang seringkali menyebabkan meningkatnya biaya transaksi (transaction cost) antara harga produk dari produsen kepada konsumen akhir. Melalui lembaga ini diharapkan setiap produsen di pedesaan dapat menikmati selisih harga jual produk dengan biaya produksi

${ }^{4}$ BUMDes sesungguhnya telah diamanatkan di dalam UU Nomor 32 Tahun 2004 tentang Pemerintahan Daerah (bahkan oleh undang-undang sebelumnya, UU Nomor 22 Tahun 1999) dan Peraturan Pemerintah (PP) Nomor 72 Tahun 2005 tentang Desa. 
yang layak dan konsumen tidak harus menanggung harga pembelian yang mahal. Membantu kebutuhan dana masyarakat yang bersifat konsumtif dan produktif. Menjadi distributor utama untuk memenuhi kebutuhan sembilan bahan pokok (sembako). Disamping itu, berfungsi menumbuh suburkan kegiatan pelaku ekonomi di pedesaan.

Definisi yang disematkan pada BUMDes dalam UU Desa yaitu badan usaha yang seluruh atau sebagian besar modalnya dimiliki oleh desa melalui penyertaan secara langsung yang berasal dari kekayaan desa yang dipisahkan guna mengelola aset, jasa pelayanan, dan usaha lainnya untuk sebesarbesarnya kesejahteraan masyarakat desa. Kalimat "untuk sebesar-besarnya kesejahteraan rakyat" adalah tujuan akhir didirikannya BUMDes. Tujuan ini tentu melekat pada semua pemerintah desa, karenanya pengetahuan yang baik akan BUMDes tentu menjadi hal yang dibutuhkan. Keinginan untuk membentuk BUMDes tanpa modal pemahaman yang baik akan pembentukan dan pengelolaannya, justru dapat menjadikan desa lebih jauh dari kata "sejahtera". Sebab, kekayaan desa yang dijadikan modal BUMDes bisa saja tidak berkembang hingga mengalami kerugian.

Oleh karena itu, gambaran mengenai pembentukan dan pengelolaan BUMDes yang terarah dapat dijadikan pedoman akan membantu pemerintah desa dalam mengelola BUMDes hingga berbuah keuntungan. Mengapa BUMDes penting bagi desa, dan bagaimanakah pedoman pembentukan dan pengelolaan BUMDes yang benar menurut peraturan perundang-undangan, khususnya UU Nomor 6 Tahun 2014?

\section{B. Pembahasan}

\section{Pentingnya BUMDes bagi Desa}

Jika dibuat perbandingan antara ketentuan BUMDes dalam UU Nomor 32 Tahun 2004 dengan UU Nomor 6 Tahun 2014 dapat diketahui ketentuan dalam UU Nomor 6 Tahun 2014 lebih elaboratif. UU Nomor 32 Tahun 2004 mengatur hanya dalam satu pasal yaitu Pasal 213, bahwa:

(1) desa dapat mendirikan badan usaha milik desa sesuai dengan kebutuhan dan potensi desa.

(2) badan usaha milik desa berpedoman pada peraturan perundangundangan.

(3) badan usaha milik desa dapat melakukan pinjaman sesuai peraturan perundang-undangan.

Penjelasan Pasal 213 ini bahwa Badan Usaha Milik Desa adalah badan hukum sebagaimana diatur dalam peraturan perundang-undangan.

Adapun UU Nomor 6 Tahun 2014 mengatur lebih terperinci. UU Desa ini mengatur tentang BUMDes pada Bab X kedalam tiga pasal:

a. Pasal 87 ayat (1) Desa dapat mendirikan Badan Usaha Milik Desa yang disebut BUM Desa; ayat (2) BUM Desa dikelola dengan semangat 
kekeluargaan dan kegotongroyongan; (3) BUM Desa dapat menjalankan usaha di bidang ekonomi dan/atau pelayanan umum sesuai dengan ketentuan peraturan perundang-undangan.

b. Pasal 88 ayat (1) Pendirian BUM Desa disepakati melalui Musyawarah Desa ayat (2) Pendirian BUM Desa (1) ditetapkan dengan Peraturan Desa. Pasal 89 hasil usaha BUM Desa dimanfaatkan untuk:

1) pengembangan usaha; dan

2) pembangunan desa, pemberdayaan masyarakat desa, dan pemberian bantuan untuk masyarakat miskin melalui hibah, bantuan sosial, dan kegiatan dana bergulir yang ditetapkan dalam Anggaran Pendapatan dan Belanja Desa.

c. Pasal 90, Pemerintah, Pemerintah Daerah Provinsi, Pemerintah Daerah Kabupaten/Kota, dan Pemerintah Desa mendorong perkembangan BUM Desa dengan:

1) memberikan hibah dan/atau akses permodalan;

2) melakukan pendampingan teknis dan akses ke pasar; dan

3) memprioritaskan BUM Desa dalam pengelolaan sumber daya alam di desa.

Beranjak dari ketentuan tersebut, sejatinya logika pendirian BUMDes didasarkan pada kebutuhan dan potensi desa, sebagai upaya peningkatan kesejahteraan masyarakat. Berkenaan dengan perencanaan dan pendiriannya, BUMDes dibangun atas prakarsa (inisiasi) masyarakat, serta mendasarkan pada prinsip-prinsip kooperatif, partisipatif, transparansi, emansipatif, akuntabel, dan sustainable dengan mekanisme berbasis anggota dan pengusahaan mandiri. Dari semua itu yang terpenting adalah bahwa pengelolaan BUMDes harus dilakukan secara profesional dan mandiri.

BUMDes merupakan pilar kegiatan ekonomi di desa yang berfungsi sebagai lembaga sosial (social institution) dan komersial (commercial institution). BUMDes sebagai lembaga sosial berpihak kepada kepentingan masyarakat melalui kontribusinya dalam penyediaan pelayanan sosial. Tujuan pendirian BUMDes antara lain dalam rangka peningkatan Pendapatan Asli Desa (PADes).

Sedangkan sebagai lembaga komersial bertujuan mencari keuntungan melalui penawaran sumberdaya lokal (barang dan jasa) ke pasar. Dalam menjalankan usahanya prinsip efisiensi dan efektifitas harus selalu ditekankan. BUMDes sebagai badan hukum, dibentuk berdasarkan tata perundang-undangan yang berlaku, ketentuan tersebut bersifat umum, sedangkan pembangunannya disesuaikan dengan kesepakatan yang terbangun di masyarakat desa. Dengan demikian, bentuk BUMDes dapat beragam di setiap desa di Indonesia. Ragam bentuk ini sesuai dengan karakteristik lokal, potensi, dan sumberdaya yang dimiliki masing-masing desa. 
Tujuan akhirnya, BUMDes sebagai instrumen modal sosial yang diharapkan menjadi jembatan yang menghubungkan desa dengan lingkup perekonomian diluarnya sehingga menjadi penguat ekonomi di pedesaan. Untuk mencapai kondisi tersebut diperlukan langkah strategis dan taktis guna mengintegrasikan potensi, kebutuhan pasar, dan penyusunan desain lembaga tersebut ke dalam suatu perencanaan. Disamping itu, perlu memperhatikan potensi lokalistik serta dukungan kebijakan (good will) dari pemerintahan di atasnya untuk mengeliminir rendahnya surplus kegiatan ekonomi desa disebabkan kemungkinan tidak berkembangnya sektor ekonomi di wilayah pedesaan. Sehingga integrasi sistem dan struktur pertanian dalam arti luas, usaha perdagangan, dan jasa yang terpadu akan dapat dijadikan sebagai pedoman dalam tata kelola lembaga.

Pendirian badan usaha harus disertai dengan upaya penguatan kapasitas dan didukung oleh kebijakan daerah (kabupaten/kota) yang memfasilitasi dan melindungi usaha ini dari ancaman persaingan para pemodal besar. Mengingat badan usaha ini merupakan lembaga ekonomi baru yang beroperasi di pedesaan dan masih membutuhkan landasan yang kuat untuk tumbuh dan berkembang. Pembangun landasan bagi pendirian BUMDes adalah Pemerintah. BUMDes dalam operasionalisasinya idealnya juga ditopang oleh lembaga moneter desa (unit pembiayaan) sebagai unit yang melakukan transaksi keuangan berupa kredit maupun simpanan. Jika kelembagaan ekonomi kuat dan ditopang kebijakan yang memadai, maka pertumbuhan ekonomi yang disertai dengan pemerataan distribusi aset kepada rakyat secara luas akan mampu menanggulangi berbagai permasalahan ekonomi di pedesaan.

Oleh karena itu, meski setiap Pemerintah Desa dapat mendirikan Badan Usaha Milik Desa (BUMDes), namun penting disadari bahwa BUMDes didirikan atas prakarsa masyarakat dan didasarkan pada potensi yang dapat dikembangkan dengan menggunakan sumberdaya lokal dan terdapat permintaan pasar. Dengan kata lain, pendirian BUMDes bukan merupakan paket instruksional yang datang dari Pemerintah, pemerintah provinsi, atau pemerintah kabupaten. Jika yang berlaku demikian dikhawatirkan BUMDes akan berjalan tidak sebagaimana yang diamanatkan di dalam undang-undang. Tugas dan peran pemerintah adalah melakukan sosialisasi dan penyadaran kepada masyarakat desa melalui pemerintah provinsi dan/atau pemerintah kabupaten tentang arti penting BUMDes bagi peningkatan kesejahteraan masyarakat. Melalui pemerintah desa masyarakat dimotivasi, disadarkan dan dipersiapkan untuk membangun kehidupannya sendiri. Pemerintah memfasilitasi dalam bentuk pendidikan dan pelatihan dan pemenuhan lainnya yang dapat memperlancar pendirian BUMDes.

Selanjutnya, mekanisme operasionalisasi diserahkan sepenuhnya kepada masyarakat desa. Untuk itu, masyarakat desa perlu dipersiapkan 
terlebih dahulu agar dapat menerima gagasan baru tentang lembaga ekonomi yang memiliki dua fungsi yakni bersifat sosial dan komersial. Dengan tetap berpegang teguh pada karakteristik desa dan nilai-nilai yang hidup dan dihormati. Maka persiapan yang dipandang paling tepat adalah berpusat pada sosialisasi, pendidikan, dan pelatihan kepada pihak-pihak yang berkepentingan terhadap peningkatan standar hidup masyarakat desa (pemerintah desa, BPD, tokoh masyarakat/ketua suku, ketua-ketua kelembagaan di pedesaan).

Melalui cara demikian diharapkan keberadaan BUMDes mampu mendorong dinamisasi kehidupan ekonomi di pedesaan. Peran pemerintah desa adalah membangun relasi dengan masyarakat untuk mewujudkan pemenuhan standar pelayanan minimal (SPM), sebagai bagian dari upaya pengembangan komunitas (development based community) desa yang lebih berdaya.

\section{Pedoman Pembentukan dan Pengelolaan BUMDes}

Kata 'Pedoman' menurut Kamus Besar Bahasa Indonesia adalah 1) alat untuk menunjukkan arah atau mata angin; 2) kumpulan ketentuan dasar yang memberi arah bagaimana sesuatu harus dilakukan; 3 ) hal (pokok) yang menjadi dasar (pegangan, petunjuk, dsb.) untuk menentukan atau melaksanakan sesuatu; atau 4) pemimpin (yang menerangkan cara menjalankan atau mengurus perkumpulan). ${ }^{5}$ Adapun kata 'pembentukan' berarti proses, perbuatan, cara membentuk. ${ }^{6}$ Sedangkan kata 'pengelolaan' berarti 1) proses, cara, perbuatan mengelola; 2) proses melakukan kegiatan tertentu dengan menggerakan tenaga orang lain; 3) proses yang membantu merumuskan kebijaksanaan dan tujuan organisasi; 4) proses yang memberikan pengawasan pada semua hal yang terlibat dalam pelaksanaan kebijaksanaan dan pencapaian tujuan. ${ }^{7}$ BUMDes adalah lembaga usaha desa yang dikelola oleh masyarakat dan pemerintahan desa dalam upaya memperkuat perekonomian desa dan dibentuk berdasarkan kebutuhan dan potensi desa.

Pedoman pembentukan dan pengelolaan berarti hal pokok yang memberi arah bagaimana cara membentuk dan bagaimana sesuatu dapat dikelola agar dapat mencapai tujuan yang diharapkan. Maka pedoman pembentukan dan pengelolaan BUMDes dapat diartikan sebagai hal pokok yang memberi arah bagaimana cara membentuk dan dan mengelola

\footnotetext{
${ }^{5}$ Tim Penyusun Kamus Pusat Pembinaan dan Pengembangan Bahasa, Kamus Besar Bahasa Indonesia, (Jakarta: Balai Pustaka, 1991), hlm. 740.

${ }^{6}$ Ibid., hlm 119.

${ }^{7}$ Ibid., hlm. 470.
} 
BUMDes agar dapat sesuai dengan tujuan yang diharapkan guna mendukung pendapatan desa dan berkontribusi dalam kesejahteraan masyarakat desa.

Dengan pengertian BUMDes adalah lembaga usaha desa yang dikelola oleh masyarakat dan pemerintahan desa dalam upaya memperkuat perekonomian desa dan dibentuk berdasarkan kebutuhan dan potensi desa, maka pendirian BUMDes merupakan potensi besar yang dapat dimaksimalkan. BUMDes menurut UU Desa didirikan antara lain dalam rangka peningkatan Pendapatan Asli Desa (PADesa).

Berangkat dari cara pandang ini, jika pendapatan asli desa dapat diperoleh dari BUMDes, maka kondisi itu akan mendorong setiap Pemerintah Desa memberikan "goodwill" dalam merespon pendirian BUMDes. Sebagai salah satu lembaga ekonomi yang beroperasi dipedesaan, BUMDes harus memiliki perbedaan dengan lembaga ekonomi pada umumnya. Ini dimaksudkan agar keberadaan dan kinerja BUMDes mampu memberikan kontribusi yang signifikan terhadap peningkatan kesejahteraan warga desa. Disamping itu, supaya tidak berkembang sistem usaha kapitalistis di pedesaan yang dapat mengakibatkan terganggunya nilai-nilai kehidupan bermasyarakat.

Terdapat 7 (tujuh) ciri utama yang membedakan BUMDes dengan lembaga ekonomi komersial pada umumnya yaitu: ${ }^{8}$

a. badan usaha ini dimiliki oleh desa dan dikelola secara bersama;

b. modal usaha bersumber dari desa (51\%) dan dari masyarakat (49\%) melalui penyertaan modal (saham atau andil);

c. operasionalisasinya menggunakan falsafah bisnis yang berakar dari budaya lokal (local wisdom);

d. bidang usaha yang dijalankan didasarkan pada potensi dan hasil informasi pasar;

e. keuntungan yang diperoleh ditujukan untuk meningkatkan kesejahteraan anggota (penyerta modal) dan masyarakat melalui kebijakan desa (village policy);

f. difasilitasi oleh Pemerintah, Pemprov, Pemkab, dan Pemdes; dan

g. pelaksanaan operasionalisasi dikontrol secara bersama (Pemdes, BPD, anggota).

BUMDes sebagai suatu lembaga ekonomi modal usahanya dibangun atas inisiatif masyarakat dan menganut asas mandiri. Ini berarti pemenuhan modal usaha BUMDes harus bersumber dari masyarakat. Meskipun demikian, tidak menutup kemungkinan BUMDes dapat mengajukan pinjaman modal kepada pihak luar, seperti dari pemerintah desa atau pihak lain, bahkan melalui pihak ketiga.

\footnotetext{
${ }^{8}$ Buku Panduan Pendirian dan Pengelolaan Badan Usaha Milik Desa (BUMDes), (Surabaya: Departemen Pendidikan Nasional Pusat Kajian Dinamika Sistem Pembangunan (PKDSP) Fakultas Ekonomi Universitas Brawijaya, 2007), hlm. 4.
} 
Beberapa ketentuan umum yang dapat dijadikan acuan dalam pengelolaan BUMDes di antaranya panduan sebagaimana dipublikasikan oleh Pusat Kajian Dinamika Sistem Pembangunan (PKDSP) Fakultas Ekonomi Universitas Brawijaya di tahun 2007, yaitu bahwa:

a. Tujuan Pendirian BUMDes, yaitu:

1) meningkatkan perekonomian desa;

2) meningkatkan pendapatan asli desa;

3) meningkatkan pengolahan potensi desa sesuai dengan kebutuhan masyarakat; dan

4) menjadi tulang punggung pertumbuhan dan pemerataan ekonomi pedesaan.

Untuk mencapai tujuan BUMDes dilakukan dengan cara memenuhi kebutuhan (produktif dan konsumtif) masyarakat melalui pelayanan distribusi barang dan jasa yang dikelola masyarakat dan Pemdes. Pemenuhan kebutuhan ini diupayakan tidak memberatkan masyarakat, mengingat BUMDes akan menjadi usaha desa yang paling dominan dalam menggerakan ekonomi desa. Lembaga ini juga dituntut mampu memberikan pelayanan kepada non-anggota (di luar desa) dengan menempatkan harga dan pelayanan yang berlaku standar pasar. Artinya terdapat mekanisme kelembagaan/tata aturan yang disepakati bersama, sehingga tidak menimbulkan distorsi ekonomi di pedesaan disebabkan usaha yang dijalankan oleh BUMDes.

Dinyatakan di dalam undang-undang bahwa BUMDes dapat didirikan sesuai dengan kebutuhan dan potensi desa. Apa yang dimaksud dengan "kebutuhan dan potensi desa" adalah kebutuhan masyarakat terutama dalam pemenuhan kebutuhan pokok; Tersedia sumberdaya desa yang belum dimanfaatkan secara optimal terutama kekayaan desa dan terdapat permintaan di pasar; tersedia sumber daya manusia yang mampu mengelola badan usaha sebagai aset penggerak perekonomian masyarakat; adanya unitunit usaha yang merupakan kegiatan ekonomi warga masyarakat yang dikelola secara parsial dan kurang terakomodasi.

BUMDes merupakan wahana untuk menjalankan usaha di desa. Apa yang dimaksud dengan "usaha desa" adalah jenis usaha yang meliputi pelayanan ekonomi desa seperti antara lain: usaha jasa keuangan, jasa angkutan darat dan air, listrik desa, dan usaha sejenis lainnya; penyaluran sembilan bahan pokok ekonomi desa; perdagangan hasil pertanian meliputi tanaman pangan, perkebunan, peternakan, perikanan, dan agrobisnis; industri dan kerajinan rakyat. 
b. Prinsip Tata Kelola BUMDes ${ }^{9}$ :

1) Prinsip Umum Pengelolaan Badan Usaha Milik Desa (BUMDes)

Pembangunan BUMDes memerlukan informasi yang akurat dan tepat tentang karakteristik kelokalan, termasuk ciri sosial-budaya masyarakatnya dan peluang pasar dari produk (barang dan jasa) yang dihasilkan. BUMDes sebagai badan usaha yang dibangun atas inisiatif masyarakat dan menganut asas mandiri, harus mengutamakan perolehan modalnya berasal dari masyarakat dan Pemdes. Meskipun demikian, tidak menutup kemungkinan BUMDes dapat memperoleh modal dari pihak luar, seperti dari pemerintah kabupaten atau pihak lain, juga pinjaman dari pihak ketiga sesuai peraturan perundang-undangan.

BUMDes didirikan dengan tujuan yang jelas. Tujuan tersebut akan direalisir di antaranya dengan cara memberikan pelayanan kebutuhan untuk usaha produktif terutama bagi kelompok miskin di pedesaan, mengurangi praktek ijon (rente) dan pelepasan uang, menciptakan pemerataan kesempatan berusaha dan meningkatkan pendapatan masyarakat desa. BUMDes harus mampu mendidik masyarakat membiasakan menabung, dengan cara demikian akan dapat mendorong pembangunan ekonomi masyarakat desa secara mandiri. Diprediksi bahwa karakteristik masyarakat desa yang perlu mendapat pelayanan utama BUMDes adalah:

a) masyarakat desa yang dalam mencukupi kebutuhan hidupnya berupa pangan, sandang, dan papan, sebagian besar memiliki mata pencaharian di sektor pertanian dan melakukan kegiatan usaha ekonomi yang bersifat usaha informal;

b) masyarakat desa yang penghasilannya tergolong sangat rendah, dan sulit menyisihkan sebagian penghasilannya untuk modal pengembangan usaha selanjutnya;

c) masyarakat desa yang dalam hal tidak dapat mencukupi kebutuhan hidupnya sendiri, sehingga banyak jatuh ke tangan pengusaha yang memiliki modal lebih kuat; dan

d) masyarakat desa yang dalam kegiatan usahanya cenderung diperburuk oleh sistem pemasaran yang memberikan kesempatan kepada pemilik modal untuk dapat menekan harga, sehingga mereka cenderung memeras dan menikmati sebagian besar dari hasil kerja masyarakat desa. Atas dasar prediksi tersebut, maka karakter BUMDes sesuai dengan ciri-ciri utamanya, prinsip yang mendasari, mekanisme dan sistem pengelolaanya.

Maka, secara umum pendirian BUMDes dimaksudkan untuk:

\footnotetext{
${ }^{9}$ Lihat Bab III yang terdiri dari Pasal 6 sampai Pasal 21 Peraturan Menteri Dalam Negeri Nomor 39 Tahun 2010 tentangBadan Usaha Milik Desa.
} 
a) meningkatkan pelayanan kepada masyarakat (standar pelayanan minimal), agar berkembang usaha masyarakat di desa;

b) memberdayakan desa sebagai wilayah yang otonom berkenaan dengan usaha-usaha produktif bagi upaya pengentasan kemiskinan, pengangguran, dan peningkatan PADes; dan

c) meningkatkan kemandirian dan kapasitas desa serta masyarakat dalam melakukan penguatan ekonomi di desa.

\section{2) Prinsip Pengelolaan BUMDes}

Prinsip-prinsip pengelolaan BUMDes penting untuk dielaborasi atau diuraikan agar dipahami dan dipersepsikan dengan cara yang sama oleh pemerintah desa, anggota (penyerta modal), BPD, Pemkab, dan masyarakat. Terdapat 6 (enam) prinsip dalam mengelola BUMDes yaitu:

a) kooperatif, Semua komponen yang terlibat di dalam BUMDes harus mampu melakukan kerja sama yang baik demi pengembangan dan kelangsungan hidup usahanya;

b) partisipatif, Semua komponen yang terlibat di dalam BUMDes harus bersedia secara sukarela atau diminta memberikan dukungan dan kontribusi yang dapat mendorong kemajuan usaha BUMDes;

c) emansipatif, Semua komponen yang terlibat di dalam BUMDes harus diperlakukan sama tanpa memandang golongan, suku, dan agama;

d) transparan, Aktivitas yang berpengaruh terhadap kepentingan masyarakat umum harus dapat diketahui oleh segenap lapisan masyarakat dengan mudah dan terbuka;

e) akuntabel, Seluruh kegiatan usaha harus dapat dipertanggungjawabkan secara teknis maupun administratif; dan

f) sustainable, Kegiatan usaha harus dapat dikembangkan dan dilestarikan oleh masyarakat dalam wadah BUMDes.

Terkait dengan implementasi Alokasi Dana Desa (ADD) ${ }^{10}$, maka proses penguatan ekonomi desa melalui BUMDes diharapkan akan lebih berdaya. Hal ini disebabkan adanya penopang, yakni dana anggaran desa yang semakin besar. Sehingga memungkinkan ketersediaan permodalan yang cukup untuk pendirian BUMDes. Jika ini berlaku sejalan, maka akan terjadi peningkatan PADesa yang selanjutnya dapat digunakan untuk kegiatan pembangunan desa.

Hal utama yang penting dalam upaya penguatan ekonomi desa adalah memperkuat kerja sama, membangun kebersamaan/menjalin kerekatan

\footnotetext{
10 Menurut Pasal 72 UU Nomor 6 Tahun 2014, Alokasi dana Desa paling sedikit 10\% (sepuluh perseratus) dari dana perimbangan yang diterima Kabupaten/Kota dalam Anggaran Pendapatan dan Belanja Daerah setelah dikurangi Dana Alokasi Khusus.
} 
disemua lapisan masyarakat desa. ${ }^{11}$ Sehingga itu menjadi daya dorong dalam upaya pengentasan kemiskinan, pengangguran, dan membuka akses pasar.

\section{3) Persiapan Pendirian BUMDes}

Aktivitas yang harus dilakukan dalam persiapan pendirian BUMDes, meliputi:

a) mendesain struktur organisasi. BUMDes merupakan sebuah organisasi, maka diperlukan adanya struktur organisasi yang menggambarkan bidang pekerjaan apa saja yang harus tercakup di dalam organisasi tersebut. Bentuk hubungan kerja (instruksi, konsultatif, dan pertanggungjawaban) antar personil atau pengelola BUMDes;

b) menyusun jobdescription (gambaran pekerjaan). Penyusunan jobdescription bagi setiap pengelola BUMDes diperlukan agar dapat memperjelas peran dari masing-masing orang. Dengan demikian, tugas, tanggung jawab, dan wewenang pemegang jabatan tidak terjadi duplikasi yang memungkinkan setiap jabatan/pekerjaan yang terdapat di dalam BUMDes diisi oleh orang-orang yang kompeten di bidangnya;

c) menetapkan sistem koordinasi. Melalui penetapan sistem koordinasi yang baik memungkinkan terbentuknya kerja sama antar unit usaha dan lintas desa berjalan efektif;

d) menyusun bentuk aturan kerja sama dengan pihak ketiga. Kerja sama dengan pihak ketiga apakah menyangkut transaksi jual beli atau simpan pinjam penting diatur ke dalam suatu aturan yang jelas dan saling menguntungkan. Penyusunan bentuk kerjasama dengan pihak ketiga diatur secara bersama dengan Dewan Komisaris BUMDes;

e) menyusun pedoman kerja organisasi BUMDes. Diperlukan AD/ART BUMDes yang dijadikan rujukan pengelola dan sesuai dengan prinsipprinsip tata kelola BUMDes.

f) menyusun desain sistem informasi. BUMDes merupakan lembaga ekonomi desa yang bersifat terbuka. Untuk itu, diperlukan penyusunan desain sistem pemberian informasi kinerja BUMDes dan aktivitas lain yang memiliki hubungan dengan kepentingan masyarakat umum. Sehingga keberadaannya sebagai lembaga ekonomi desa memperoleh dukungan dari banyak pihak;

g) menyusun rencana usaha (business plan). Penyusunan rencana usaha penting untuk dibuat dalam periode 1 sampai dengan 3 tahun. Sehingga para pengelola BUMDes memiliki pedoman yang jelas apa yang harus dikerjakan dan dihasilkan dalam upaya mencapai tujuan yang ditetapkan dan kinerjanya menjadi terukur;

\footnotetext{
${ }^{11}$ Pasal 87 ayat (2) UU Nomor 6 Tahun 2014 menyebutkan bahwa BUMDes dikelola dengan semangat kekeluargaan dan kegotongroyongan.
} 
h) menyusun sistem administrasi dan pembukuan. Bentuk administrasi dan pembukuan keuangan harus dibuat dalam format yang mudah, tetapi mampu menggambarkan aktivitas yang dijalankan BUMDes. Hakikat dari sistem administrasi dan pembukuan adalah pendokumentasian informasi tertulis berkenaan dengan aktivitas BUMDes yang dapat dipertanggungjawabkan. Dan secara mudah dapat ditemukan, disediakan ketika diperlukan oleh pihak-pihak yang berkepentingan;

i) melakukan proses rekruitmen. Untuk menetapkan orang-orang yang bakal menjadi pengelola BUMDes dapat dilakukan secara musyawarah. Namun pemilihannya harus di dasarkan pada kriteria tertentu. Kriteria itu dimaksudkan agar pemegang jabatan di BUMDes mampu menjalankan tugas-tugasnya dengan baik. Untuk itu, persyaratan bagi pemegang jabatan di dalam BUMDes penting dibuat oleh Dewan Komisaris. Selanjutnya dibawa ke dalam forum rembuk desa untuk disosialisasikan dan ditawarkan kepada masyarakat. Proses selanjutnya adalah melakukan seleksi terhadap pelamar dan memilih serta menetapkan orang-orang yang paling sesuai dengan kriteria yang dibuat; serta

j) menetapkan sistem penggajian dan pengupahan. Agar pengelola BUMDes termotivasi dalam menjalankan tugas-tugasnya, maka diperlukan adanya sistem imbalan yang dirasakan bernilai. Pemberian imbalan bagi pengelola BUMDes dapat dilakukan dengan berbagai macam cara seperti, pemberian gaji yang berarti pengelola BUMDes menerima sejumlah uang dalam jumlah yang tetap setiap bulannya. Jumlah yang diterima dapat bervariasi tergantung dari banyak sedikitnya beban pekerjaan yang harus diselesaikan melalui cara penawaran. Pemberian insentif jika pengelola mampu mencapai target yang ditetapkan selama periode tertentu. Besar kecilnya jumlah uang yang dapat dibayarkan kepada pengelola.

4) Pendirian dan Pengelolaan BUMDes

a) cara pendirian BUMDes: pendirian BUMDes berdasar pada Perda Kabupaten; diatur berdasarkan Perdes; satu desa, hanya terdapat satu BUMDes; Pemkab memfasilitasi pendirian BUMDes; BUMDes dapat didirikan dalam bentuk Usaha Bersama (UB) atau bentuk lainnya, tetapi bukan Koperasi, PT, Badan Usaha Milik Daerah, CV, UD atau lembaga keuangan (BPR);

b) empat tahapan pendirian BUMDes ${ }^{12}$ : melakukan rembuk desa guna membuat kesepakatan pendirian BUMDes; melakukan identifikasi

\footnotetext{
12 Pasal 5 ayat (2) Peraturan Menteri Dalam Negeri Nomor 39 Tahun 2010 tentangBadan Usaha Milik Desa.
} 
potensi dan permintaan terhadap produk (barang dan jasa) yang akan ditawarkan BUMDes; menyusun AD/ART; dan mengajukan legalisasi badan hukum ke notaris untuk memperoleh pengesahan; serta

c) pengelolaan BUMDes dan persyaratan pemegang jabatan: BUMDes harus dikelola secara profesional dan mandiri sehingga diperlukan orang-orang yang memiliki kompetensi untuk mengelolanya. Latar belakang pendidikan bagi pemegang jabatan ini penting agar dapat menjalankan peran dan fungsinya sesuai dengan tuntutan pekerjaan. Selain itu: perlu disusun adanya job desk/deskripsi tanggung jawab dan wewenang pada masing-masing lini organisasi, sebagai panduan kerja; kegiatan yang bersifat lintas desa perlu dilakukan koordinasi dan kerja sama antar Pemerintah Desa dalam pemanfaatan sumber-sumber ekonomi; kerja sama dengan pihak ketiga oleh pengelola harus dengan konsultasi dan persetujuan Dewan Komisaris BUMDes; dalam kegiatan harian, maka pengelola harus mengacu pada tata aturan yang sudah disepakati bersama sebagaimana yang telah tertuang dalam AD/ART BUMDes, serta sesuai prinsip-prinsip tata kelola BUMDes; Pengelolaan harus transparan/terbuka sehingga ada mekanisme check and balance baik oleh pemerintahan desa maupun masyarakat; dan perlu disusun rencana-rencana pengembangan usaha.

5) Monitoring dan evaluasi,dibuat mekanisme/prosedur pengawasan.

Disamping dilakukan oleh dewan komisaris pengawasan bisa ditambah unsur dari pemerintah kabupaten. Sebab, Pemerintah Kabupaten juga berperan untuk memfasilitasi usaha BUMDes. Proses monitoring dilakukan secara berkelanjutan, sehingga bisa memantau kegiatan BUMDes secara baik. Evaluasi dilakukan per triwulan atau sewaktu-waktu jika dianggap perlu sesuai ketentuan AD/ART.

6) Pertanggungjawaban Pengelola

Dalam proses pertanggungjawabaan pengelolaan BUMDes, maka disarikan pendapat PKDSP FE UB dalam Buku Panduan Pendirian dan Pengelolaan Badan Usaha Milik Desa (BUMDes), sebagai berikut:

a) Setiap akhir periode tahun anggaran, pengelola wajib menyusun laporan pertanggungjawaban untuk disampaikan dalam forum musyawarah desa yang menghadirkan elemen pemerintahan desa, elemen masyarakat serta seluruh kelengkapan struktur organisasi BUMDes.

b) Laporan Pertanggungjawaban, antara lain memuat:

(1) Laporan Kinerja Pengelola selama satu periode/tahunan.

(2) Kinerja usaha yang menyangkut realisasi kegiatan usaha, upaya pengembangan, indikator keberhasilan, dsb.

(3) Laporan keuangan termasuk Rencana Pembagian Laba Usaha. 
(4) Rencana-rencana pengembangan usaha yang belum terealisasi.

(5) Proses pertanggungjawaban dilakukan sebagai upaya evaluasi tahunan serta upaya-upaya pengembangan kedepan.

(6) Mekanisme dan Tata Tertib Pertanggungjawaban ini disesuaikan dengan AD-ART.

7) Karakteristik BUMDes

Karakteristik BUMDes di antaranya: berbentuk badan hukum, berusaha di bidang perekonomian (jasa, manufaktur, dan perdagangan), Modal terdiri dari penyertaan Pemdes dan penyertaan masyarakat dengan perbandingan $51 \%$ dan $49 \%$, menjadi pusat kegiatan ekonomi masyarakat desa, menjadi salah satu sumber pendapatan desa, dan memberikan layanan pada masyarakat. Adapun usaha yang dapat dijalankan melalui BUMDes, antara lain: Pasar desa, simpan pinjam, Waserda, sumber air, transportasi, objek wisata desa, home industry, kerajinan rakyat, perikanan darat, peternakan, pertanian, dan agroindustri.

\section{Penutup}

\section{Kesimpulan}

UU Desa Nomor 6 Tahun 2014 telah menjadi pengaturan yang komprehensip tentang desa. Berbeda dari UU Nomor 32 Tahun 2004, pengaturan mengenai BUMDes dalam UU Desa yang baru ini lebih lengkap. BUMDes tetap diposisikan sebagai suatu lembaga perekonomian desa yang memiliki peranan penting dalam mewujudkan kesejahteraan masyarakat, desa dan pemerintah desa. Tata kelola yang profesional dengan mengacu pada pedoman pembentukan BUMDes berdasarkan peraturan perundangundangan menjadi prasyarat berjalannya BUMDes secara baik. Dengan demikian, kegiatan BUMDes yang profesional dan ideal dapat menjadi bagian dari usaha peningkatkan ekonomi lokal dan regional dalam lingkup perekonomian nasional.

\section{Saran}

Berdasarkan hasil kajian diketahui bahwa urgensi keberadaan BUMDes sebagai usaha mandiri desa sangatlah penting. Oleh karena itu, realisasi pembentukan dan pengelolaan BUMDes dengan panduan peraturan perundang-undangan perlu ditindaklanjuti ditingkat kabupaten/kota berupa perda dan ditingkat desa berupa peraturan desa. 


\section{Daftar Pustaka}

\section{A. Buku}

Cheema, Shabbir G, dan Rondinelli, 1984. Decentralization and Development, Policy Implementation in Developing Countries, California: Sage Publications.

Christina, Anita, et. al., 2001. Jaman Daulat Rakyat: Dari Otonomi Daerah ke Demokratisasi, Jogjakarta: Lappera.

Departemen Pendidikan Nasional Pusat Kajian Dinamika Sistem Pembangunan (PKDSP), 2007. Buku Panduan Pendirian dan Pengelolaan Badan Usaha Milik Desa (BUMDes), Surabaya: Fakultas Ekonomi Universitas Brawijaya.

Dharmayuda, I Made, 2001. Desa Adat Kesatuan Masyarakat Hukum Adat di Provinsi Bali, Denpasar: Upada Sastra.

Forum Pengembangan Pembaharuan Desa (FPPD), 2004. Laporan Hasil Studi ADD (Anggaran Dana Desa), Kabupaten Slayar, Sulawesi Selatan, Yogyakarta: FPPD.

Juliantara, Dadang, 2003. Pembaruan Desa, Bertumpu Pada Yang Terbawah, Jogjakarta: Lappera.

Kartohadikoesoemo, Soetardjo, 2004. Desa, Jakarta: PN Balai Pustaka.

Muljadi, Arief, 2005. Landasan dan Prinsip Hukum Otonomi Daerah dalam NKRI, Jakarta: Prestasi Pustaka.

Santosa, Andri, et.al., 2002. Otonomi Daerah dan Gelombang Baru Penyeragaman Hukum Lokal, Jakarta: HuMA.

Seidman, Ann., Seidman, Robert B., and Nalin, Abeyserkere, 2001. Penyusunan Rancangan Undang-Undang Dalam Perubahan Masyarakat Yang Demokratis, ELIPS.

Simarmata, Rikardo, 2006. Pengakuan Hukum terhadap Masyarakat Adat di Indonesia, Jakarta: RIPP/UNDP.

Soimin, 2010. Pembentukan Perundang-undangan Negara di Indonesia, Yogyakarta: UIIPress,

Widjaja, H.A.W., 2010. Otonomi Desa: Merupakan Otonomi Yang Asli, Bulat dan Utuh, Jakarta: Raja Grafindo.

\section{B. Peraturan Perundang-undangan}

Peraturan Menteri Dalam Negeri Nomor 39 Tahun 2010 tentang Badan Usaha Milik Desa.

Peraturan Pemerintah Nomor 72 Tahun 2005 tentang Desa.

Undang-Undang Nomor 32 Tahun 2004 tentang Pemerintahan Daerah.

Undang-Undang Nomor 6 Tahun 2014 tentang Desa. 


\section{Makalah dan Kamus}

Pambudi, Himawan, “Aspek Sosiologi Politik Pemerintahan Desa”, makalah disampaikan dalam lokakarya Rancangan Penyusunan UU tentang Pemerintahan Daerah, kerja sama PSHK dan DPD RI, Hotel Harris, Jakarta, 6 Maret 2007.

Tim Penyusun Kamus Pusat Pembinaan dan Pengembangan Bahasa, 1988, Kamus Besar Bahasa Indonesia, Jakarta: Balai Pustaka.

Tim Penyusun Kamus Pusat Pembinaan dan Pengembangan Bahasa, 1991, Kamus Besar Bahasa Indonesia, Jakarta: Balai Pustaka. 